\title{
The effect of macroinvertebrate exclusion on leaf breakdown rates in two upland Colombian streams
}

\author{
Bladimir Zúñiga-Céspedes ${ }^{1,2,3}$, María del Carmen Zúñiga ${ }^{1,2}$ \& Julián Chará2 \\ 1. Universidad del Valle. Departamento de Biología. Grupo de Investigaciones Entomológicas, Calle 13 No 100-00, Cali, \\ Colombia; maczuniga@gmail.com \\ 2. Centro para la Investigación en Sistemas Sostenibles de Producción Agropecuaria, CIPAV, Carrera 25 No 6-62, Cali, \\ Colombia; julian@fun.cipav.org.co \\ 3. Department of Zoology and Center for Ecology, Southern Illinois University, Carbondale, Illinois, 62901-6501, USA; \\ bladomir@gmail.com
}

Received 29-V-2017. Corrected 20-X-2017. Accepted 25-XI-2017.

\begin{abstract}
Macroinvertebrate shredders have been widely recognized as an important functional feeding group that contributes to leaf decomposition in temperate streams, but little is known about their role in upland Neotropical streams. In this study, we investigated the effect of macroinvertebrate exclusion on leaf breakdown rates in two upland streams in Colombia. The study was carried out between January and April of 2009, including the dry season and the beginning of the wet season. We measured leaf mass loss using coarse- (15 $\mathrm{mm}$; accessible to macroinvertebrates) and fine- $(200 \mu \mathrm{m}$; macroinvertebrates excluded) mesh litter bags that were anchored with wood stakes to the bottom of each stream and recovered after 7, 14, 21, 28, and 56 days. We selected leaves from two dominant plant species and used three leaf treatments: two single species (Palicourea cuatrecasasii and Critoniopsis ursicola) and mixed-species (P. cuatrecasasii and C. ursicola). We compared leaf breakdown rates between the Peña Bonita and Marianela stream, mesh-sizes, and leaf treatments. Macroinvertebrates that colonized the litter bags were measured for density and biomass and categorized in functional feeding groups. In general, there were no significant differences in breakdown rates between the streams and the mesh-sizes. In contrast, leaf breakdown rates had significant differences between all leaf species, where C. ursicola had higher breakdown rates than mixed-species, and P. cuatrecasasii. Macroinvertebrate exclusion did not affect leaf breakdown rates and their assemblages were composed by high densities of collectors (mainly Chironomidae) and few shredders with a large body size. The similar macroinvertebrate colonization between leaf species, the relatively slow breakdown rates, and the shredder scarcity, suggest that leaves were a refractory substrate. Further studies should include leaf species with different nutritional qualities and larger spatial-temporal scales to test the hypothesis of shredder presence and its role on leaf decomposition in upland Colombian streams. Rev. Biol. Trop. 66(1): 457-467. Epub 2018 March 01.
\end{abstract}

Key words: leaf breakdown rates; functional feeding groups; shredders; tropical streams.

Headwater streams are generally shaded by riparian vegetation which limits autotrophic production and is considered the main source of allochthonous production that supports the food webs (Fisher \& Likens, 1973; Vannote, Minshall, Cummins, Sedell, \& Cushing, 1980; Webster \& Benfield, 1986; Wallace, Eggert, Meyer, \& Webster, 2015). Within the stream, leaf litter is fragmented by physical (e.g., abrasion by current velocity) and biological (invertebrate shredding and microbial breakdown) activity (Gessner, Chauvet, \& Dobson, 1999); in consequence, leaf litter can be incorporated into microbial and invertebrate biomass, fragmented to fine particulate organic matter (FPOM), and mineralized to $\mathrm{CO}_{2}$ (Webster et al., 1999). Leaf litter breakdown and the subsequent FPOM production is manly mediated by shredders; this FPOM is the main source of energy for invertebrate collectors and 
may fuel the detritus pathway in low and high order streams (Vannote et al., 1980; Webster et al., 1999). Therefore, shredders are considered a key functional feeding group (FFG) that supports upper trophic levels (e.g., invertebrate predators, amphibians, and fishes) and contributes to the FPOM production that is consumed by collector-gatherers and collector-filterers (e.g., larval black flies, larval midges; Cummins, Petersen, Howard, Wuycheck, \& Holt, 1973; Cummins \& Klug, 1979).

Within the stream, leaf litter is generally organized as a complex matrix of various species in the streambed (Swan \& Palmer, 2006; Kominoski et al., 2007). Shredders might selectively consume high litter quality (e.g., low carbon: nutrient ratios, low lignin content, low leaf toughness) and use the more recalcitrant leaves for case construction (e.g., caddisfly larvae; Sanpera-Calbet, Lecerf, \& Chauvet, 2009) or for refuge from predators (Jabiol et al., 2014). Shredders are also selective feeders (Arsuffi \& Suberkropp, 1989; Graça et al., 2001), such that mixed-species with different food qualities can influence their assemblages (e.g., diversity, growth rate, feeding activity), and consequently, breakdown rates (Swan \& Palmer, 2004; Kominoski et al., 2007; Handa et al., 2014). In the present study, we selected two dominant riparian plant species and selected three treatments (two single species and one mixed-species) to evaluate the effect of leaf identity on macroinvertebrate assemblages.

Although shredders have been widely recognized as an important FFG in temperate streams, little is known about their role on leaf decomposition in Neotropical upland streams. Shredders distribution may be related with the water temperature-elevation relationship in tropical streams (Irons, Oswood, Stout, \& Pringle, 1994). For instance, Yule et al. (2009) hypothesized that shredder abundance and diversity might be higher in upland than lowland tropical streams and, in consequence, this FFG could have an important role in leaf litter breakdown in upland streams. They found that upland streams had more abundance and diversity of shredders than lowland streams in peninsular Malaysia. In Ecuadorian streams, Jacobsen, Schultz and Encalada (1997) found that the water temperature-elevational gradient is correlated with invertebrate taxa composition. Moreover, they found similarities in invertebrate composition between a lowland stream in Denmark and an upland stream in Ecuador. Similarly, in a study of elevational patterns of macroinvertebrates in Ecuadorian streams, Jacobsen (2003) found that the beta diversity (i.e., taxon turnover among streams) increased with elevation.

Several studies have shown that macroinvertebrate shredders are important on leaf breakdown in Colombian streams (Mathuriau \& Chauvet, 2002; Chará, Baird, Telfer, \& Giraldo, 2007; Chará-Serna, Chará, Zúñiga, Pearson, \& Boyero, 2012; Eyes-Escalante, Rodríguez-Barrios, \& Gutiérrez-Moreno, 2012; Longo \& Blanco, 2014). In this sense, according to the water temperature-elevation relationship and the hypothesis that shredders may be important on leaf decomposition in tropical upland streams, we evaluated if macroinvertebrates exclusion affects leaf litter breakdown rates in two Colombian mountain streams (1 911 and 2560 m elevation). We used coarse- and fine-mesh litter bags to investigate the effect of macroinvertebrate exclusion on leaf litter breakdown. We hypothesized that, in cool upland Colombian streams, (1) leaf litter breakdown rates are mainly mediated by macroinvertebrates and (2) based on the river continuum concept (Vannote et al., 1980), macroinvertebrate assemblage (i.e., density, species richness, and biomass) on litter bags is mainly composed by collectors and shredders.

\section{MATERIALS AND METHODS}

The study sites are in the Wildlife Sanctuary Otún-Quimbaya (Marianela Stream) and the Nevados National Natural Park (Peña Bonita Stream); both are managed by the National System of Protected Areas (Villegas, 2006). The experiments were carried out in secondorder tributaries within the Otún River watershed (Risaralda, Colombia) between January 
and April of 2009, including the dry season and the beginning of the wet season. The Peña Bonita $\left(4^{\circ} 43^{\prime} 32^{\prime \prime} \mathrm{N} \& 75^{\circ} 29^{\prime} 18^{\prime \prime} \mathrm{W}, 2560\right.$ $\mathrm{m}$ elevation) and Marianela $\left(4^{\circ} 42^{\prime} 57^{\prime \prime} \mathrm{N} \&\right.$ 75³3'35" W, 1911 m elevation) streams are in protected and conserved areas of the Andean mountain range, with no direct influence of human activities (Fig. 1). Annual mean temperature is $14.8^{\circ} \mathrm{C}$, and average annual rainfall $2638 \mathrm{~mm}$, ranging from 1550 to $3500 \mathrm{~mm}$. Precipitation occurs throughout the year with two peaks of high precipitation from March to June and from September to November, and two periods of low precipitation from July to August and from December to February (Villegas, 2006).

According to previous studies (CharáSerna et al., 2012; the Center for Research in Sustainable Agricultural Production Systems [CIPAV], unpublished data), the streams are relatively different in their physicochemical parameters and channel characteristics (e.g., mean width, $\%$ pool habitats, $\%$ boulder, alkalinity, conductivity, nitrates). However, important parameters such as water temperature, $\mathrm{pH}$, dissolved oxygen, and total nitrogen are relatively similar between the two streams (Table 1). The study sites are in the lower montane moist forest according to Holdridge life zones (UAESPNN, 2005) and covered by evergreen forest dominated mainly by trees.
Both streams are dominated by plant species such as Chusquea subulata L. G. Clark (Poaceae), Critoniopsis ursicola (Cuatrec.)

TABLE 1

Physicochemical parameters and channel characteristics in the Marianela (Chará-Serna et al., 2012) and Peña Bonita (CIPAV, unpublished data) streams

\begin{tabular}{|c|c|c|}
\hline & Marianela & Peña Bonita \\
\hline Altitude (m asl) & 1911 & 2560 \\
\hline Mean width (m) & 3.8 & 1.4 \\
\hline Mean depth (cm) & 18 & 14 \\
\hline Pool habitats (\%) & 67 & 27 \\
\hline Riffle habitats (\%) & 33 & 73 \\
\hline Leaf litter in pools (\%) & 40 & 43 \\
\hline Leaf litter in riffles $(\%)$ & 25 & 46 \\
\hline \multicolumn{3}{|l|}{ Substrate composition (\%): } \\
\hline Boulders $(>256 \mathrm{~mm})$ & 60 & 20 \\
\hline Cobbles $(64-256 \mathrm{~mm})$ & 0 & 30 \\
\hline Pebbles (16-64 mm) & 20 & 20 \\
\hline Gravel $(2-16 \mathrm{~mm})$ & 20 & 15 \\
\hline Sand $(<2 \mathrm{~mm})$ & 0 & 15 \\
\hline Water temperature $\left({ }^{\circ} \mathrm{C}\right)$ & 14.3 & 12.9 \\
\hline $\mathrm{pH}$ & 7.5 & 7.9 \\
\hline Alkalinity $\left(\mathrm{mg} / \mathrm{L} \mathrm{CaCO}_{3}\right)$ & 17.9 & 88 \\
\hline Conductivity $(\mu \mathrm{S} / \mathrm{cm})$ & 35 & 171 \\
\hline Dissolved oxygen (mg/L) & 7.1 & 7.6 \\
\hline Total Nitrogen (mg N/L) & $<1.6$ & $<1.6$ \\
\hline Nitrites $\left(\mathrm{mg} \mathrm{N}-\mathrm{NO}_{2} / \mathrm{L}\right)$ & $<0.01$ & $<0.02$ \\
\hline Nitrates $\left(\mathrm{mg} \mathrm{N}-\mathrm{NO}_{3} / \mathrm{L}\right)$ & 0.7 & 0.23 \\
\hline $\begin{array}{l}\text { Total phosphorous } \\
\left(\mathrm{mg} \mathrm{P}-\mathrm{PO}_{4} / \mathrm{L}\right)\end{array}$ & 0.04 & 0.18 \\
\hline
\end{tabular}

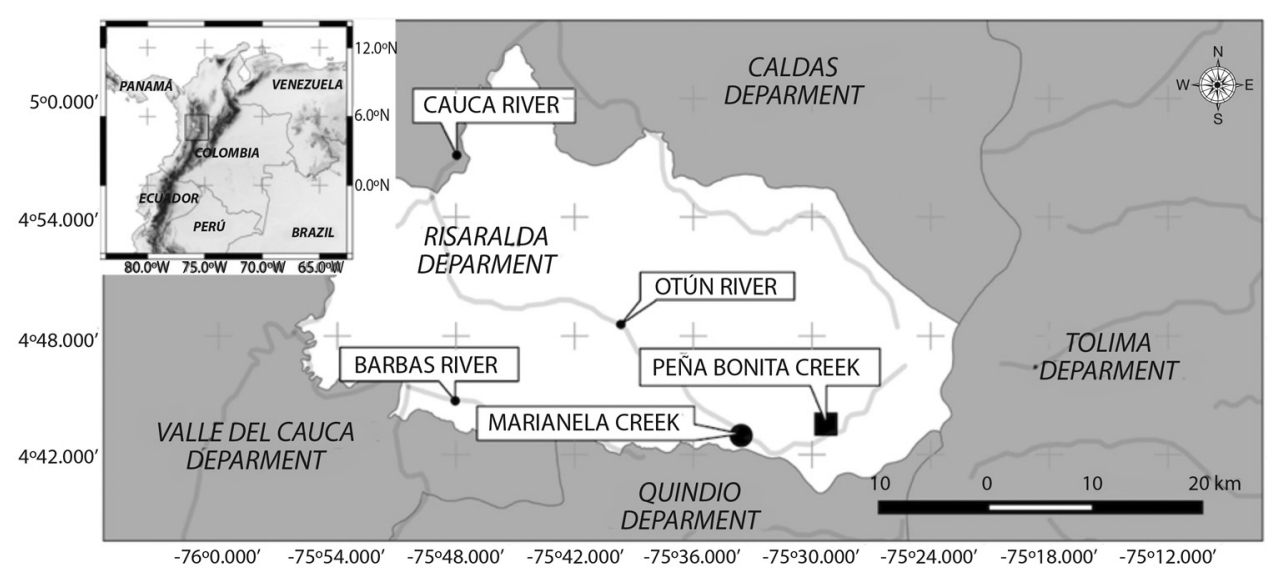

Fig. 1. Experimental sites in the Otún River watershed, Colombia. The insets show the location of the department of Risaralda, the Otún River watershed and the Peña Bonita and Marianela streams. 
H. Rob. (Asteraceae), Saurauia cuatrecasasiana R. E. Schult. (Actinidiaceae), Oreopanax floribundum Decne. \& Planch. (Araliaceae), Chrysochlamys colombiana (Cuatrec.) Cuatrec. (Clusiaceae), and Palicourea cuatrecasasii Standl. ex Steyerm. (Rubiaceae).

Senescent freshly-fallen leaves of two dominant riparian species (C. ursicola and $P$. cuatrecasasii) were used in the experiments. To compare leaf breakdown rates between leaf species (single- and mixed- species) and examine the effect of macroinvertebrate exclusion, air-dried leaves were weighed $(2.52 \pm$ $0.08 \mathrm{~g}$; mean \pm Standard Error, SE) and placed in coarse-mesh $(15 \mathrm{~mm}$, accessible to macroinvertebrates) and fine-mesh $(200 \mu \mathrm{m}$, macroinvertebrates excluded) litter bags (size of the litter bags: $15 \times 15 \mathrm{~cm}$ ). Four leaf types were used in each stream: $C$. ursicola only, $P$. cuatrecasasii only, mixed-species (C. ursicola $+P$. cuatrecasasii; $1.25 \pm 0.08 \mathrm{~g}$ per species), and artificial leaves (plastic leaves with an equal area to C. ursicola and P. cuatrecasasii). Artificial leaves were used to determine that the particulate organic matter, accumulated in the litter bags from transported material, was not a confounding factor that attracted macroinvertebrate colonists (Dangles, Guerold, \& Usseglio-Polatera, 2001).

All the leaves used in the experiments were air-dried for 48 hours and ten additional leaf-packs (mean weight $=2.29 \pm 0.06 \mathrm{~g}$ ) per leaf species were oven-dried $\left(60^{\circ} \mathrm{C}\right)$ for $72 \mathrm{~h}$. A correction factor for humidity (D) was used for the leaves before the exposure of the litter bags in the streams (Bärlocher, 2005). The average correction factor was estimated according to the equation: $\mathrm{D}=$ oven-dried mass/air-dried mass. Litter bags were placed in pool areas where non-experimental leaf litter was naturally accumulated by both streams (Table 1). In addition, the use of stream pools in the experiments reduced the risk of loss of the litter bags and may reduce the macroinvertebrate drift by strong flood events. Litter bags were anchored with wood stakes to the bottom of each stream (16 cm of depth) and recovered after 7, 14, 21, 28 , and 56 days. These sampling dates were selected according to Rueda-Delgado, Wantzen and Tolosa (2006) and we included the day 21 in our experiment. Using a full factorial design with three replicates, this design resulted in the deployment of three (replicates) $\times$ three (leaf types $) \times$ two $($ mesh sizes $) \times$ two $($ streams $) \times$ five (exposure times) $=180$ litter bags, plus 30 coarse-mesh litter bags containing artificial leaves $(\mathrm{N}=210)$. An additional group of litter bags $(n=36)$ was recovered at day 0 (i.e., litter bags non-exposed in the streams) to determine handling losses (Bärlocher, 2005). After their recovery, litter bags were stored in ice-boxes and transported to the laboratory to be processed.

In the laboratory, litter bags content was placed over a sieve $(74 \mu \mathrm{m})$ to separate the leaves from the rest of the material. Leaves were gently washed with running tap water and macroinvertebrates were separated and preserved in vials with ethyl alcohol (96\%). Leaves were oven-dried until constant weight (36 hours, $60{ }^{\circ} \mathrm{C}$ ) to calculate the remaining dry mass. Leaves were then ignited in a muffle furnace at $550{ }^{\circ} \mathrm{C}$ for four hours to calculate the ash-free dry mass (AFDM). Macroinvertebrates were sorted and identified to the lowest taxonomic level using the taxonomic keys of Posada-García and Roldán-Pérez (2003) and Domínguez and Fernández (2009). In addition, macroinvertebrates were classified into FFGs using a local study (Chará-Serna et al., 2012). Macroinvertebrate density of litter bags was expressed as numbers per unit mass of leaf litter (no./g leaf AFDM) (Rincón \& Covich, 2014). Biomass (dry mass, DM) was measured in each litter bag by oven-drying $\left(60{ }^{\circ} \mathrm{C}, 48\right.$ h) and weighing macroinvertebrates sorted by taxon to calculate dry mass per leaf remaining mass $( \pm 0.01 \mathrm{mg})$.

Breakdown rates $(k)$ of each leaf species were calculated using the exponential decay model $M_{t}=M_{0} e^{-k t}$, where $M_{t}$ is the remaining AFDM at time $t$ and $M_{0}$ is the initial mass. This exponential decay equation was converted to a linear form $\left(\ln \left(M_{t}\right)=\ln \left(M_{0}\right)\right.$ $k t$ ) which determines the linear regression to calculate the slope (the decay coefficient $k$ ). 
Leaf breakdown rates were compared between leaf species and between mesh sizes in each stream using two-way repeated measures (RM) ANOVA, followed by the Tukey's test (HSD) for pairwise comparison if significance was found. The litter bags were our experimental units which were separated approximately 50 $\mathrm{cm}$ between them. Likewise, macroinvertebrate density and biomass were compared between streams and between leaf types using two-way RM ANOVA, followed by Tukey's test. Data from FFG biomass (mg DM per litterbag of collectors, shredders, and predators) from both streams were pooled since we did not find significant differences between the streams ( $\mathrm{P}$ $>0.05$ ) and were compared between leaf types using one-way RM ANOVA. Density in each FFG was compared using the Friedman rank sum test because the data did not meet the ANOVA assumptions of normality, despite the
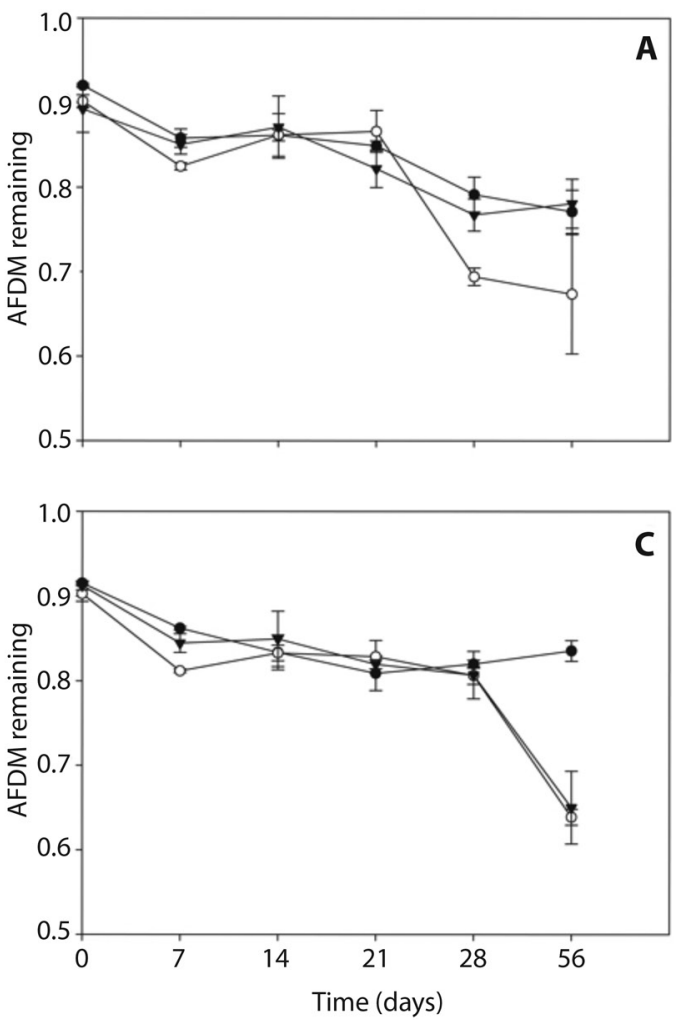

transformations performed previously (with FFGs as treatments and days as blocks). The relationships between leaf mass loss and macroinvertebrate biomass were investigated by Pearson product moment correlation. All analyses were performed with SigmaPlot (version 11.0; Systat software, Chicago, IL) with significance threshold set at $\alpha=0.05$.

\section{RESULTS}

Leaf breakdown rates were significantly different between leaf species in Peña Bonita (two-way RM ANOVA, $\mathrm{F}_{2,10}=41.51, \mathrm{P}<$ 0.001 ) and Marianela (two-way RM ANOVA, $\left.\mathrm{F}_{2,10}=85.07, \mathrm{P}<0.001\right)$ streams after 56 days. Specifically, C. ursicola had higher breakdown rates than mixed-species and $P$. cuatrecasasii $(\mathrm{P}<0.05$; Fig. 2 and Table 2). Leaf species
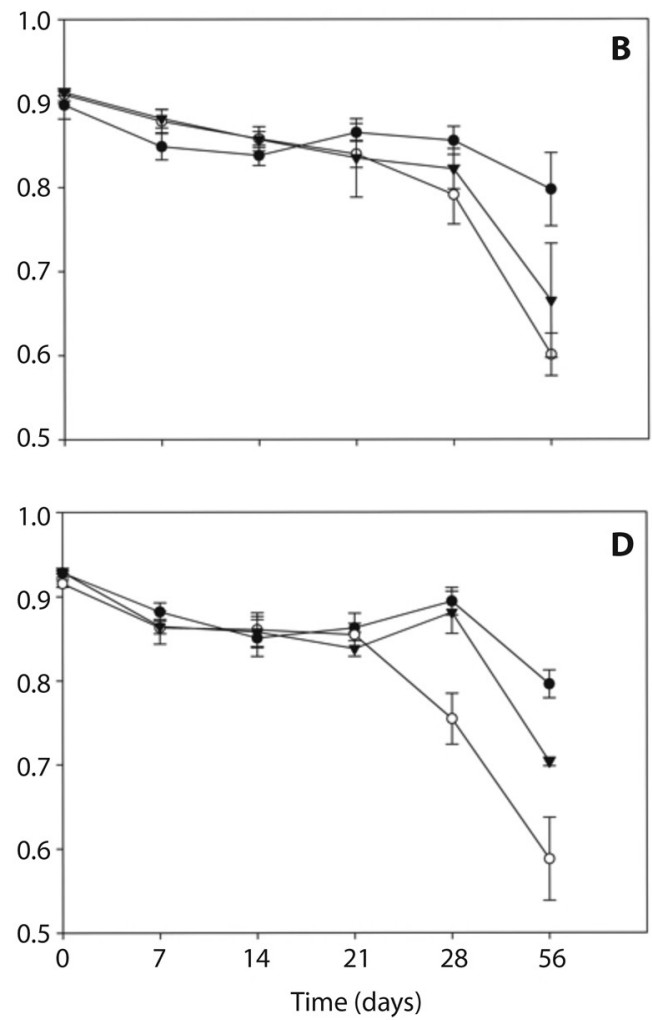

Fig. 2. Remaining ash-free dry mass (AFDM; means $\pm \mathrm{SE}$ ) of P. cuatrecasasii (black circle), C. ursicola (white circle), and mixed-species (inverted black triangle) incubated in fine-mesh (A and B) and coarse-mesh (C and D) litter bags in the Marianela (A and C) and Peña Bonita (B and D) streams. 
TABLE 2

Exponential litter decay rates as a function of time in days $(-k / \mathrm{d})$

\begin{tabular}{lccc}
\multicolumn{1}{c}{ Litter treatment } & $-k(/ \mathrm{d})$ & $\mathrm{SE}$ & $\mathrm{R}^{2}$ \\
P. cuatrecasasii (fine-mesh, PB) & 0.0052 & 0.0008 & 0.70 \\
C. ursicola (fine-mesh, PB) & 0.0091 & 0.0006 & 0.94 \\
Litter mixtures (fine-mesh, PB) & 0.0078 & 0.0008 & 0.85 \\
P. cuatrecasasii (coarse-mesh, PB) & 0.0048 & 0,0006 & 0.78 \\
C. ursicola (coarse-mesh, PB) & 0.0097 & 0.0007 & 0.92 \\
Litter mixtures (coarse-mesh, PB) & 0.0065 & 0.0006 & 0.88 \\
P. cuatrecasasii (fine-mesh, MN) & 0.0060 & 0.0007 & 0.81 \\
C. ursicola (fine-mesh, MN) & 0.0086 & 0.0010 & 0.81 \\
Litter mixtures (fine-mesh, MN) & 0.0062 & 0.0009 & 0.73 \\
P. cuatrecasasii (coarse-mesh, MN) & 0.0051 & 0.0009 & 0.67 \\
C. ursicola (coarse-mesh, MN) & 0.0085 & 0.0007 & 0.89 \\
Litter mixtures (coarse-mesh, MN) & 0.0083 & 0.0007 & 0.89
\end{tabular}

$-\mathrm{k}(/ \mathrm{d})=$ mean, $\mathrm{SE}=$ standard error. $\mathrm{PB}=$ Peña Bonita stream. $\mathrm{MN}=$ Marianela stream. $\mathrm{R}^{2}=$ coefficient of determination.

had more than $50 \%$ of mass remaining after 56 days in both streams and leaf mass remaining ranged between $\sim 90 \%$ and $\sim 70 \%$ from 0 to 28 days of exposure in all leaf species (Fig. 2). Leaf breakdown was similar between mesh sizes in Peña Bonita stream in all leaf species (two-way RM ANOVA, $\mathrm{F}_{1,10}=0.382, \mathrm{P}=$ 0.564 ) and it was significantly higher in finemesh than coarse-mesh litter bags in Marianela stream (two-way RM ANOVA, $\mathrm{F}_{1,10}=15.073$, $\mathrm{P}=0.012$ ). However, the effect of mesh size on leaf breakdown rates was found only in one leaf species (C. ursicola). Indeed, we found a significant interaction only between this leaf species and mesh size in the Marianela stream (two-way RM ANOVA, $\mathrm{F}_{2,10}=14.493, \mathrm{P}=$ 0.001 ). It means that the effect of mesh size on leaf breakdown was not attributed to macroinvertebrates but by the leaf characteristics of this plant species.

On the other hand, there was no significant difference in macroinvertebrate density between streams (two-way RM ANOVA, $\mathrm{F}_{1,12}$ $=0.36, \mathrm{P}=0.576$ ) and natural leaves had a higher macroinvertebrate density than artificial leaves ( $\mathrm{P}<0.05$; Fig. 3A). Macroinvertebrate density peaked at day 14 , and then returned to the levels of day 7 for the rest of the experiments, with no significant differences between natural leaves $(\mathrm{P}>0.05$; Fig. 3A). Furthermore, collectors had the highest density $($ mean $=19.3$ no./g leaf AFDM), followed by very low densities of shredders (mean $=2.5$ no. $/ \mathrm{g}$ leaf AFDM) and predators $($ mean $=0.4$ no./g leaf AFDM) (Friedman rank sum test, $\mathrm{P}<0.05$; Fig. 3C). The family Chironomidae (Diptera) had the highest relative density $(74.4 \%)$, followed by a very low density of Phylloicus (Trichoptera; $7.8 \%$ ). Macroinvertebrate biomass was not significantly different between streams (two-way RM ANOVA, $\mathrm{F}_{1,12}=2.56, \mathrm{P}=0.185$ ) or leaf species (two-way RM ANOVA, $\mathrm{F}_{3,12}=2.88, \mathrm{P}$ $=0.079)$. Although the statistical analysis did not detect differences between natural and artificial leaves, there was a trend for lower macroinvertebrate biomass in artificial leaves (mean $=0.53 \mathrm{mg} \mathrm{DM}$ ) (Fig. 3B). Macroinvertebrate biomass was the highest after 56 days in all leaf species; however, there was no clear pattern of steady increase in biomass through time (Fig. 3B). Additionally, there was a significant difference in biomass between FFGs (one-way RM ANOVA, $\left.F_{2,8}=6.132, \mathrm{P}=0.024\right)$, with shredders presenting higher biomass (mean $=1.17 \mathrm{mg} \mathrm{DM}$ ) than collectors (mean $=0.51$ $\mathrm{mg} \mathrm{DM})$ and predators (mean $=0.24 \mathrm{mg} \mathrm{DM}$ ) ( $<<0.05$; Fig. 3D). The genera Anchytarsus (Coleoptera: Ptilodactilydae) and Phylloicus 

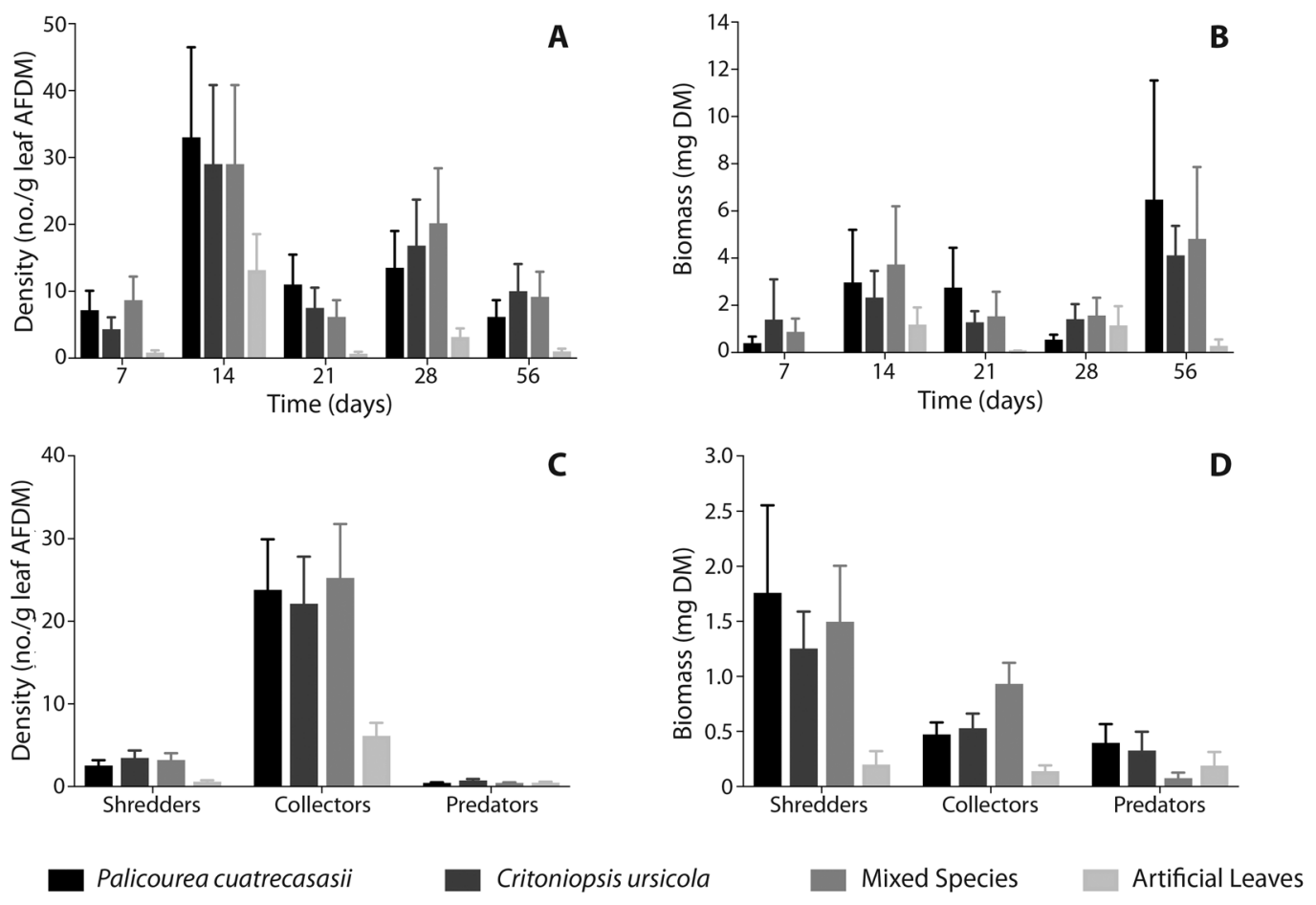

Fig. 3. Macroinvertebrate density (means $+\mathrm{SE}$ ) and biomass in P. cuatrecasasii, C. ursicola, mixed-species, and artificial leaves in the Peña Bonita and Marianela streams (combined). The bar represents the mean and the line on the bar the standard error.

(both classified as shredders) were the taxa with the highest relative biomass (both taxa had $52.2 \%$ of relative biomass), followed by Chironomidae and the genus Heterelmis (Coleoptera) (both classified as collectors), which had $17.6 \%$ of relative biomass. Although shredders had the highest biomass (Fig. 3D), no significant relationship was observed between macroinvertebrate biomass and leaf mass loss in any leaf species (correlation coefficients: $C$. ursicola $=-0.0668, P$. cuatrecasasii $=-0.273$, mixed-species $=-0.0934 ; \mathrm{P}>0.05)$.

\section{DISCUSSION}

Contrary to our initial hypothesis, shredders were scarce and had a minor effect on leaf breakdown rates in the present study. Our results indicated that the leaf species selected were of low quality and consequently, processing rates of leaf litter were medium and slow, according to the categories stated by Petersen and Cummins (1974). Leaf quality and the presence of one shredder keystone species may interact in a complex way to promote leaf decomposition (Encalada, Calles, Ferreira, Canhoto, \& Graça, 2010). For example, in a study carried out in the same region of our streams at $1580 \mathrm{~m}$ elevation, Chará et al. (2007) reported similar proportions of shredder biomass (50 - $68 \%$ ), with leaf breakdown rates even lower than that found in this study $(-k=0.0008-0.0058)$. However, contrary to our study, they found that shredders contributed to leaf processing, where the leaf breakdown rates were higher in coarse-mesh than in fine-mesh litter bags. These authors used different leaf species and reported a high abundance of shredder taxa of the genera Triplectides and Nectopsyche (Leptoceridae: Trichoptera) which were not found in our study. In addition, and unexpectedly, leaf breakdown rate of $C$. ursicola was significantly 
higher on fine-mesh than coarse-mesh litter bags in the Marianela stream. It suggests that the use of mesh litter bags affected leaf mass loss independently of macroinvertebrate presence. Other factors such as physical breakdown by stream discharge and/or microbial colonization may affect decomposition differently when the litter bags are in different locations of the highly heterogeneous tropical mountain streams (Rueda-Delgado et al., 2006; Boyero et al., 2012).

The similar macroinvertebrate colonization between leaf species, the relatively slow processing rates, and the shredder paucity suggest that leaves were a highly refractory substrate. Although we were unable to measure leaf quality, our results indicated that it might have had an important role in the leaf breakdown rates in our experiment. Leaf litter characteristics could have influenced the low macroinvertebrate colonization and, furthermore, other leaf species with higher nutritional quality located in the streambed could have conditioned the attractiveness of macroinvertebrates in the litter bags (Leroy \& Marks, 2006; Kominoski et al., 2007; Sanpera-Calbet et al., 2009). Various studies have found that litter quality might affect leaf breakdown rates and macroinvertebrate colonization (Leroy \& Marks, 2006; Graça \& Cressa, 2010; Blanco \& Gutiérrez-Isaza, 2014). Moreover, when we compared macroinvertebrate assemblages between natural and artificial leaves, we found that artificial leaves were colonized by few macroinvertebrates, mainly Chironomidae, Simuliidae, and the leaf-case caddisfly Phylloicus (Trichoptera). It suggests that artificial leaves may be used as substrate or refuge for these macroinvertebrates and their food may be obtained from the FPOM, the water column, and biofilm attached on it.

In our study, shredder biomass was higher than that of other FFGs; however, this contribution was related to few individuals with large body size of the genera Anchytarsus (Coleoptera) and Phylloicus (Trichoptera). This caddisfly contributes to leaf degradation by using the leaves for case construction (Rincón \& Martínez, 2006); however, we observed few evidence of leaf shredding in the leaves. Yule et al. (2009) hypothesized that the large body size of shredders may enable the consumption of recalcitrant leaves (e.g., low nitrogen content, high lignin concentration, and high toughness). Shredders with large body size, morphological features such as large mouthparts, and physiological adaptations such as higher tolerance to secondary metabolites, might allow the consumption of refractory leaves, contrary to shredders with small body size (Wantzen \& Wagner, 2006; Yule et al., 2009). Further studies are necessary to evaluate if the presence of few shredders with large body size and low leaf quality are common patterns in upland Colombian streams.

In terms of the limitations of our study, we used only two leaf species in a stream reach of $100 \mathrm{~m}$ length. This restricts any generalization about the role of macroinvertebrates on leaf breakdown since our experiments did not encompass the wide range of combinations of leaf traits (Kier et al., 2005; Antonelli \& Sanmartín, 2011) and stream characteristics that may be encountered in tropical mountain streams (Lewis, 2008). Moreover, our experiment ended on day 56, when leaf mass remaining was around $50 \%$ for all leaf species. It restricts the conclusions about later decomposition stages of the leaf species used in the experiment. Despite these limitations, the results of this study highlighted the importance of leaf species identity and shredder species composition in leaf processing. Shredders (e.g., semi-aquatic cockroaches, decapods, and aquatic insects) and riparian plant species are composed by a high diversity of taxa in tropical streams (Antonelli \& Sanmartín, 2011; Boyero et al., 2012). We suggest that litter quality was an important factor that affected macroinvertebrate assemblages in our leaf species; therefore, further studies should investigate a wider variety of leaf traits on larger spatial-temporal scales in Colombian streams. 


\section{ACKNOWLEDGMENTS}

We thank Corporación Autónoma Regional de Risaralda (CARDER) and Centro de Visitantes "La Pastora" (Risaralda) for their logistic support in the field work. We also thank to Laboratorio de Propagación de Semillas and Laboratorio de Investigaciones Entomológicas (Universidad del Valle). A special thanks to Ranulfo González, and Cristian Román for their valuable support, and to Blanca C. Ramos, Oscar Ascuntar, Paula Casas, Lina P. Giraldo, and Diana Montoya who helped in the field work. We also thank three anonymous reviewers for valuable advice and suggestions during the development of this manuscript. Additional thanks are extended to Colciencias and the Francisco José de Caldas National Fund for Science, Technology, and Innovation in Colombia for the institutional support to CIPAV (0823-2013). Part of the data used in this paper came from the International Foundation for Science (Grant A/4178-1 to Julián Chará).

\section{RESUMEN}

Efecto de la exclusión de macroinvertebrados sobre las tasas de descomposición de la hojarasca en dos ríos de alta montaña en Colombia. Los macroinvertebrados fragmentadores han sido ampliamente reconocidos como un importante grupo funcional alimenticio que contribuye a la descomposición de la hojarasca en quebradas del hemisferio norte, pero poco se sabe sobre su papel en quebradas de montaña neotropicales. En el presente estudio investigamos el efecto de la exclusión de los macroinvertebrados sobre las tasas de fragmentación de la hojarasca en dos quebradas de montaña en Colombia. Nuestra hipótesis es que la fragmentación de la hojarasca es mediada principalmente por macroinvertebrados fragmentadores en quebradas de montaña en Colombia. Este estudio fue llevado a cabo entre enero y abril 2009, incluyendo la época seca y el comienzo de la época de lluvias. Se midieron las pérdidas de masa de hojarasca usando bolsas de malla gruesa (15 mm; accesible a macroinvertebrados) y fina (200 $\mu \mathrm{m}$; macroinvertebrados excluidos); estas fueron atadas con estacas de madera al fondo de cada quebrada y recuperadas transcurridos 7, 14, 21, 28 y 56 días. Se seleccionó hojarasca de dos especies dominantes en los sitios de estudio y se usaron tres tratamientos para las bolsas de hojarasca: Critoniopsis ursicola, Palicourea cuatrecasasii y una mezcla de estas dos especies. Se compararon las tasas de fragmentación de la hojarasca entre las dos quebradas, los dos tipos de malla y las especies de hojarasca. Los macroinvertebrados que colonizaron las bolsas de hojarasca fueron medidos en términos de densidad, biomasa y categorizados en grupos funcionales alimenticios. En general, nuestros resultados no mostraron diferencias significativas en las tasas de fragmentación de la hojarasca entre las quebradas y entre los tipos de malla. En contraste, las tasas de fragmentación presentaron diferencias significativas entre las especies de hojarasca; específicamente, C. ursicola tuvo tasas más altas de fragmentación que las especies mezcladas y que $P$. cuatrecasasii. Con respecto a los macroinvertebrados, el presente estudio encontró que su exclusión no tuvo un efecto sobre las tasas de fragmentación y los ensamblajes estuvieron compuestos por una alta densidad de recolectores (principalmente de la familia Chironomidae) y pocos fragmentadores con gran tamaño corporal. La colonización similar de macroinvertebrados entre las especies de hojarasca, las relativamente lentas tasas de fragmentación, sugieren que las hojas fueron un sustrato refractario. Futuros estudios deberían incluir especies de hojarasca con diferentes calidades nutricionales y una mayor escala espacio-temporal para estudiar la hipótesis de la presencia de fragmentadores en quebradas de montaña en Colombia.

Palabras clave: tasas de fragmentación; grupos funcionales alimenticios; fragmentadores; quebradas tropicales.

\section{REFERENCES}

Antonelli, A., \& Sanmartín, I. (2011). Why are there so many plant species in the Neotropics? Taxon, 60(2), 403-414.

Arsuffi, T. L., \& Suberkropp, K. (1989). Selective feeding by shredders on leaf-colonizing stream fungi: comparison of macroinvertebrate taxa. Oecologia, 79(1), 30-37.

Bärlocher, F. (2005). Leaf mass loss estimated by litter bag technique. In M. A. S. Graça, F. Bärlocher, \& M. O. Gessner (Eds.), Methods to study litter decomposition: a practical guide (pp. 37-42). Dordrecht, The Netherlands: Springer.

Blanco, J. F., \& Gutiérrez-Isaza, N. (2014). Leaf litter mass loss rates and associated fauna of tree species commonly used in neotropical riparian reforestation. Acta Biológica Colombiana, 19(1), 91-100.

Boyero, L., Pearson, R. G., Dudgeon, D., Ferreira, V., Graça, M. A. S., Gessner, M. O., ... Barmuta, L. A. (2012). Global patterns of stream detritivore distribution: implications for biodiversity loss in changing climates. Global Ecology and Biogeography, 21(2), 134-141.

Chará, J., Baird, D., Telfer, T., \& Giraldo, L. (2007). A comparative study of leaf breakdown of three native tree species in a slowly-flowing headwater stream 
in the Colombian Andes. International Review of Hydrobiology, 92(2), 183-198.

Chará-Serna, A. M., Chará, J. D., Zúñiga, M. del C., Pearson, R. G., \& Boyero, L. (2012). Diets of leaf litterassociated invertebrates in three tropical streams. Annales de Limnologie - International Journal of Limnology, 48(2), 139-144.

Cummins, K. W., Petersen, R. C., Howard, F. O., Wuycheck, J. C., \& Holt, V. I. (1973). The utilization of leaf litter by stream detritivores. Ecology, 54(2), 336-345.

Cummins, K. W., \& Klug, M. J. (1979). Feeding ecology of stream invertebrates. Annual Review of Ecology and Systematics, 10(1), 147-172.

Dangles, O., Guerold, F., \& Usseglio-Polatera, P. (2001). Role of transported particulate organic matter in the macroinvertebrate colonization of litter bags in streams. Freshwater Biology, 46(5), 575-586.

Domínguez, E., \& Fernández, H. R. (2009). Macroinvertebrados bentónicos sudamericanos: sistemática y biología. Tucumán, Argentina: Fundación Miguel Lillo.

Encalada, A. C., Calles, J., Ferreira, V., Canhoto, C. M., \& Graça, M. A. S. (2010). Riparian land use and the relationship between the benthos and litter decomposition in tropical montane streams. Freshwater Biology, 55, 1719-1733.

Eyes-Escalante, M. D. C., Rodríguez-Barrios, J. A., \& Gutiérrez-Moreno, L. C. (2012). Descomposición de la hojarasca y su relación con los macroinvertebrados acuáticos del río Gaira (Santa Marta-Colombia). Acta Biológica Colombiana, 17, 77-92.

Fisher, S. G., \& Likens, G. E. (1973). Energy flow in Bear Brook, New Hampshire: an integrative approach to stream ecosystem metabolism. Ecological Monographs, 43(4), 421-439.

Gessner, M. O., Chauvet, E., \& Dobson, M. (1999). A perspective on leaf litter breakdown in streams. Oikos, 85(2), 377-384.

Graça, M. A. S., Cressa, C., Gessner, T. M. O., Feio, M. J., Callies, K. A., \& Barrios, C. (2001). Food quality, feeding preferences, survival and growth of shredders from temperate and tropical streams. Freshwater Biology, 46(7), 947-957.

Graça, M. A. S., \& Cressa, C. (2010). Leaf quality of some tropical and temperate tree species as food resource for stream shredders. International Review of Hydrobiology, 95(1), 27-41.

Handa, I. T., Aerts, R., Berendse, F., Berg, M. P., Bruder, A., Butenschoen, O., ... McKie, B. G. (2014). Consequences of biodiversity loss for litter decomposition across biomes. Nature, 509, 218-221.
Irons, J. G., Oswood, M. W., Stout, R., \& Pringle, C. M. (1994). Latitudinal patterns in leaf litter breakdown: is temperature really important? Freshwater Biology, $32(2), 401-411$.

Jabiol, J., Cornut, J., Danger, M., Jouffroy, M., Elger, A., \& Chauvet, E. (2014). Litter identity mediates predator impacts on the functioning of an aquatic detritusbased food web. Oecologia, 176(1), 225-235.

Jacobsen, D., Schultz, R., \& Encalada, A. (1997). Structure and diversity of stream invertebrate assemblages: the influence of temperature with altitude and latitude. Freshwater Biology, 38(2), 247-261.

Jacobsen, D. (2003). Altitudinal changes in diversity of macroinvertebrates from small streams in the Ecuadorian Andes. Archiv für Hydrobiologie, 158(2), 145-167.

Kier, G., Mutke, J., Dinerstein, E., Ricketts, T. H., Küper, W., Kreft, H., \& Barthlott, W. (2005). Global patterns of plant diversity and floristic knowledge: Global plant diversity. Journal of Biogeography, 32(7), 1107-1116.

Kominoski, J. S., Pringle, C. M., Ball, B. A., Bradford, M. A., Coleman, D. C., Hall, D. B., \& Hunter, M. D. (2007). Nonadditive effects of leaf litter species diversity on breakdown dynamics in a detritus-based stream. Ecology, 88, 1167-1176.

Leroy, C. J., \& Marks, J. C. (2006). Litter quality, stream characteristics and litter diversity influence decomposition rates and macroinvertebrates. Freshwater Biology, 51(4), 605-617.

Lewis, W. (2008). Physical and chemical features of tropical flowing waters. In D. Dudgeon (Ed.), Tropical stream ecology (pp. 1-22). Amsterdam, The Netherlands: Elsevier Inc.

Longo, M., \& Blanco, J. F. (2014). Shredders are abundant and species-rich in tropical continental-island low-order streams: Gorgona Island, Tropical Eastern Pacific, Colombia. Revista de Biología Tropical, 62(1), 85-105.

Mathuriau, C., \& Chauvet, E. (2002). Breakdown of leaf litter in a neotropical stream. Journal of the North American Benthological Society, 21(3), 384-396.

Petersen, R. C., \& Cummins, K. W. (1974). Leaf processing in a woodland stream. Freshwater Biology, 4(4), 343-368.

Posada-García, J. A., \& Roldán-Pérez, G. (2003). Clave ilustrada y diversidad de las larvas de Trichoptera en el Noroccidente de Colombia. Caldasia, 25(1), 169-192.

Rincón, J., \& Martínez, I. (2006). Food quality and feeding preferences of Phylloicus sp. (Trichoptera: 
Calamoceratidae). Journal of the North American Benthological Society, 25(1), 209-215.

Rincón, J., \& Covich, A. (2014). Effects of insect and decapod exclusion and leaf litter species identity on breakdown rates in a tropical headwater stream. Revista De Biología Tropical, 62, 143.

Rueda-Delgado, G., Wantzen, K. M., \& Tolosa, M. B (2006). Leaf-litter decomposition in an Amazonian floodplain stream: effects of seasonal hydrological changes. Journal of the North American Benthological Society, 25(1), 233-249.

Sanpera-Calbet, I., Lecerf, A., \& Chauvet, E. (2009). Leaf diversity influences in-stream litter decomposition through effects on shredders. Freshwater Biology, 54(8), 1671-1682.

Swan, C. M., \& Palmer, M. A. (2004). Leaf diversity alters litter breakdown in a Piedmont stream. Journal of the North American Benthological Society, 23(1), 15-28.

Swan, C. M., \& Palmer, M. A. (2006). Composition of speciose leaf litter alters stream detritivore growth, feeding activity and leaf breakdown. Oecologia, 147(3), 469-478.

Unidad Administrativa Especial del Sistema de Parques Nacionales Naturales (UAESPNN). (2005). Sistema de Parques Nacionales Naturales de Colombia, a través de sus planes de manejo. Bogotá, Colombia: Panamericana Editores.
Vannote, R. L., Minshall, G. W., Cummins, K. W., Sedell, J. R., \& Cushing, C. E. (1980). The river continuum concept. Canadian Journal of Fisheries and Aquatic Sciences, 37(1), 130-137.

Villegas, B. (2006). Colombia: Parques Nacionales Naturales. Bogotá, Colombia: Villegas Editores.

Wallace, J. B., Eggert, S. L., Meyer, J. L., \& Webster, J. R. (2015). Stream invertebrate productivity linked to forest subsidies: 37 stream-years of reference and experimental data. Ecology, 96(5), 1213-1228.

Wantzen, K. M., \& Wagner, R. (2006). Detritus processing by invertebrate shredders: a neotropical-temperate comparison. Journal of the North American Benthological Society, 25(1), 216-232.

Webster, J. R., \& Benfield, E. F. (1986). Vascular plant breakdown in freshwater ecosystems. Annual Review of Ecology and Systematics, 17(1), 567-594.

Webster, J. R., Benfield, E. F., Ehrman, T. P., Schaeffer, M. A., Tank, J. L., Hutchens, J. J., \& D'angelo, D. J. (1999). What happens to allochthonous material that falls into streams? A synthesis of new and published information from Coweeta. Freshwater Biology, 41(4), 687-705.

Yule, C. M., Leong, M. Y., Liew, K. C., Ratnarajah, L., Schmidt, K., Wong, H. M., ... Boyero, L. (2009). Shredders in Malaysia: abundance and richness are higher in cool upland tropical streams. Journal of the North American Benthological Society, 28(2), 404-415. 